\title{
Perancangan Just In Time Di Proses Produksi Dalam Pengendalian Persediaan Bahan Baku Komponen Otomotif Pada PT Chuhatsu Indonesia
}

\author{
Chairul Anwar', Asep Endih Nurhidayat ${ }^{2}$ \\ Fakultas Teknik Dan Ilmu Komputer, JurusanTeknik Industri, Universitas Indraprasta PGRI Jakarta \\ J1 Raya Tengah No 80 RT 6/RW 1 Gedong Kec Pasar Rebo Jakarta Timur \\ Email: chairul.anwar1288@gmail.com, aennoerhidayat@gmail.com
}

\begin{abstract}
Abstrak
PT Chuhatsu Indonesia adalah perusahaan manufaktur yang bergerak dibidang komponen otomotif, salah satu produknya adalah coil spring untuk jenis mobil toyota. Permasalahan yang terjadi di perusahaan ini adanya sisa bahan baku yang tidak terpakai dalam pembuatan produk sehingga menimbulkan biaya simpan digudang. Tujuan penelitian ini mengetahui jumlah pengiriman optimal setiap kali pesan, kuantitas pengiriman optimal, kuantitas pesanan, frekuensi pembelian bahan baku pertahun, mengetahui total biaya persediaan dan biaya penghematan dengan sistem just in time. Dari perhitungan kebijakan perusahaan masih belum maksimal dan belum efisien untuk biaya persediaan. Adapun bahan baku untuk pemakaian periode tahun 2016 sebanyak $163.379 \mathrm{~kg}, 2017$ sebanyak $165.643 \mathrm{~kg}$ dan 2018 sebanyak $164.620 \mathrm{~kg}$. Biaya persediaan yang terdiri dari biaya pemesanan dan penyimpanan menurut perhitungan perusahaan tahun $2016 \mathrm{Rp} 18.342 .670,50,2017 \mathrm{Rp}$ 19.744.301,52, dan $2018 \mathrm{Rp} 21.094 .967,25$. Dalam perhitungan sistem just in time periode tahun $2016 \mathrm{Rp}$ 6.767.451,60, 2017 Rp 7.149.413,74, dan 2018 Rp 8.606.915,82. Maka penghematan yang didapat perusahaan dalam biaya persediaan dengan sistem just in time tahun $2016 \mathrm{Rp} 11.575 .218,9,2017 \mathrm{Rp} 12.594 .887,78$, dan 2018 Rp 12.488.051,43.
\end{abstract}

Kata Kunci: pengendalian persediaan bahan baku, Just In Time, optimal, biaya persediaan minimum.

\begin{abstract}
PT Chuhatsu Indonesia is a manufacturing company engaged in automotive components, one of its products is coil spring for Toyota cars. The problem that occurs in this company is the presence of unused raw materials in the manufacture of products, which causes storage costs in the warehouse. The research objective is to determine the optimal amount of delivery per order, optimal delivery quantity, order quantity, frequency of purchasing raw materials per year, to see the total cost of inventory and management costs with a timely system. From the calculation, the company policy is still not optimal and inefficient for inventory costs. The raw materials for use in the 2016 period were 163,379 kg, 2017 as many as 165,643 kg and 2018 as many as $164,620 \mathrm{~kg}$. Inventory costs which consist of ordering and storage costs according to the 2016 calculation of IDR 18,342,670.50, 2017 IDR 19,744,301.52, and 2018 IDR 21,094,967.25. In the calculation of the system, only in the period of 2016 IDR 6,767,451.60, 2017 IDR 7,149,413.74, and 2018 IDR 8,606,915.82. Then the management obtained from the inventory costs with the system in 2016 was IDR 11,575,218.9, 2017 IDR 12,594,887.78, and 2018 IDR 12,488,051.43.
\end{abstract}

Keywords: control of raw material inventory, just in time, optimal, minimum inventory costs.

\section{PENDAHULUAN}

Perusahaan pada umumnya didirikan untuk mendapatkan laba. Pada perusahaan yang menghasilkan produk berupa barang, usaha untuk mendapatkan laba dilakukan dengan cara mengolah bahan baku menjadi barang jadi atau barang setengah jadi, berbeda dengan perusahaan jasa yang hanya menyediakan pelayanan jasa pada konsumen untuk mendapatkan laba. Sehingga dalam perusahaan pengadaan bahan baku sangat besar pengaruhnya terhadap kelancaran proses produksi. Untuk melakukan proses produksi bahan baku merupakan unsur yang paling efektif didalam proses tersebut. Just In Time suatu metode pengendalian produksi berlebihan untuk memastikan bahwa semua proses membuat produk sesuai dengan kecepatan penjualan. Dalam rangka mengurangi pemborosan seperti waktu inspeksi (inspection time), waktu inspeksi timbul karena adanya ketidakyakinan produk yang di produksi sehingga dibutuhkan lagi waktu untuk memastikan apakah produk yang dihasilkan lebih mempunyai kualitas yang baik, waktu perpindahan (move time), waktu terjadi aktivitas-aktivitas yang berhubungan mulai dari penerimaan bahan baku, pemindahan bahan baku dan komponen produksi, awal pemindahan produk setengah jadi ke gudang, produk jadi untuk menunggu pengiriman, waktu tunggu (waiting time), waktu yang terjadi saat pemrosesan bahan baku menjadi produk setengah jadi hingga ke proses operasi berikutnya. Dengan adanya waktu tunggu ini selain menghambat kelancaran proses produksi, hal ini juga akan memperbesar biaya produksi secara keseluruhan (Hakim, 2015). Just In Time berpengaruh dalam mengurangi persediaan sampai pada tingkat yang sangat 
rendah. Usaha untuk mencapai tingkat persediaan sampai tingkat yang tidak signifikan sangat penting untuk kesuksesan Just In Time. Namun gagasan untuk mencapai persediaan yang tidak signifikan akan menentang alasan-alasan tradisional untuk menyimpan persediaan yang telah disebutkan sebelumnya dan filosofi pemecahan masalah yang secara berkelanjutan dan memaksa mendukung produksi yang ramping (Pristianingrum, 2017).

Just In Time berpengaruh dalam mengurangi persediaan sampai pada tingkat yang sangat rendah. Usaha untuk mencapai tingkat persediaan sampai tingkat yang tidak signifikan sangat penting untuk kesuksesan Just In Time. Namun gagasan untuk mencapai persediaan yang tidak signifikan akan menentang alasan-alasan tradisional untuk menyimpan persediaan yang telah disebutkan sebelumnya dan filosofi pemecahan masalah yang secara berkelanjutan dan memaksa mendukung produksi yang ramping. Tujuan JIT adalah meningkatkan keuntungan dengan mereduksi biaya dan meningkatkan kualitas. Manfaat yang paling jelas dari penggunaan JIT adalah pengurangan dalam persediaan WIP. Disamping mereduksi investasi persediaan, maka biaya-biaya fasilitas, peralatan dan tenaga kerja yang lebih rendah akan dapat dicapai (Nasution, dkk., 2008). Dengan just in time ini maka kedatangan persediaan bahan baku dapat tepat pada saat dibutuhkan tanpa adanya keterlambatan atau percepatan. "inventory hides problems" persediaan yang cukup dapat mengatasi masalah kemacetan produksi adalah moto yang sudah ditinggalkan saat sekarang ini. Untuk membangkitkan kondisi just in time ini, perusahaan harus menekan variabilitas atau penyimpangan yang ditimbulkan oleh penyebab internal maupun eksternal (Detiana, 2011).

\section{METODE PENELITIAN}

Metode dan prosedur merupakan langkah-langkah yang dilakukan untuk menganalisis data dengan membuatnya menjadi informasi, tujuan dari analisis data adalah mendeskripsikan data sehingga dapat dipahami dengan mudah. Just In Time merupakan filosofi yang dipusatkan pada pengurangan biaya melalui eliminasi persediaan. Konsep just in time itu sendiri merupakan suatu konsep yang bersifat universal dan dapat diterapkan oleh perusahaan manapun yang berada di seluruh dunia.

Perusahaan didalam menerapkan just in time, selain memperhatikan hubungan dengan konsumen, perusahaan juga harus menjalin hubungan yang harmonis terhadap para pemasok.

Jenis penelitian ini yang digunakan yaitu menggunakan penelitian kuantitatif dan data yang digunakan adalah data primer, data yang diambil adalah hasil pengamatan secara langsung dibagian gudang dan produksi dalam persediaan bahan baku dan pemakaian bahan baku di proses produksi. Pada gambar 1 menunjukan langkah-langkah penelitian.

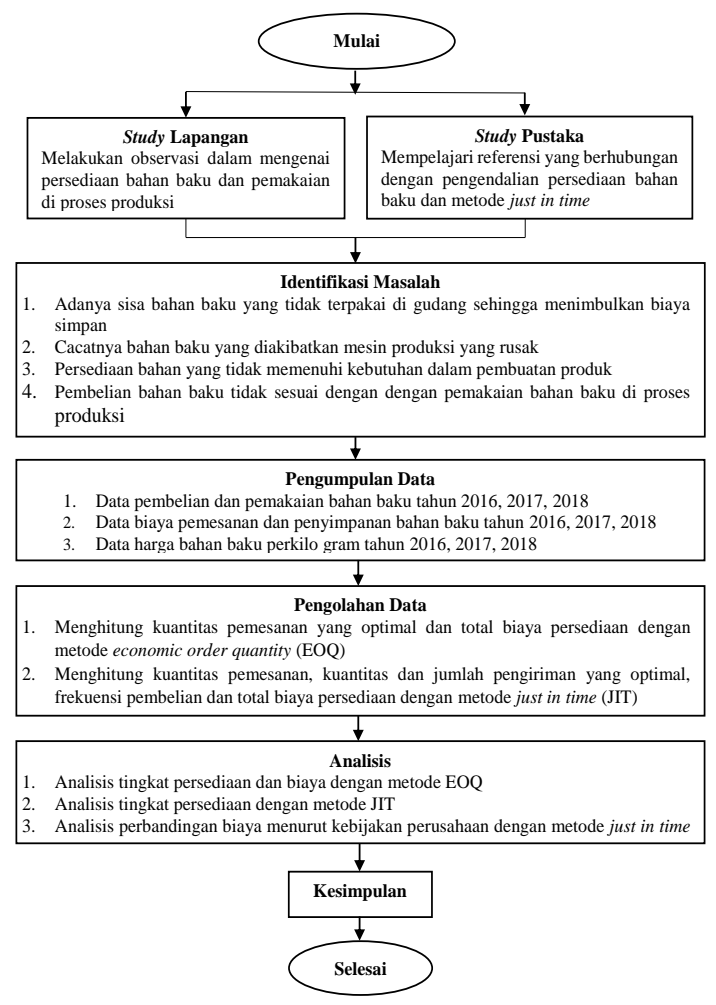

Gambar 1. Langkah-langkah Penelitian 


\section{HASIL DAN PEMBAHASAN} dilakukan:

Dalam menentukan hasil dari penelitian langkah-langkah pengolahan data dalam pembahasan yang

1. Pengumpulan Data

Berdasarkan data yang diperoleh dari PT Chuhatsu Indonesia diketahui frekuensi pembelian dan data pembelian serta pemakaian bahan baku kawat baja untuk membuat produk coil spring selama periode tahun 2016, 2017, dan 2018 berikut tabel 1 pembelian, pemakaian dan sisa bahan baku.

Tabel 1 Pembelian, Pemakaian dan Sisa Bahan Baku

\begin{tabular}{ccccccc}
\hline Tahun & $\begin{array}{c}\text { Frekuensi } \\
\text { pembelian }\end{array}$ & $\begin{array}{c}\text { Persediaan } \\
\text { awal } \\
/ \mathrm{kg}\end{array}$ & $\begin{array}{c}\text { Pembelian } \\
/ \mathrm{kg}\end{array}$ & $\begin{array}{c}\text { Total } \\
\text { persediaan/ } \\
\mathrm{kg}\end{array}$ & $\begin{array}{c}\text { Pemakaian } \\
/ \mathrm{kg}\end{array}$ & $\begin{array}{c}\text { Sisa } \\
/ \mathrm{kg}\end{array}$ \\
\hline 2016 & 12 & 3.220 & 163.434 & 166.654 & 163.379 & 3.275 \\
2017 & 12 & 3.275 & 165.638 & 168.913 & 165.643 & 3.270 \\
2018 & 12 & 3.270 & 165.065 & 168.335 & 164.620 & 3.715 \\
\hline
\end{tabular}

Dari tabel diatas dapat diketahui rata-rata kuantitas pembelian bahan baku kawat baja selama satu tahun menurut kebijakan perusahaan periode 2016, 2017, 2018 adalah pembelian bahan baku dibagi frekuensi pembelian. Berikut tabel 2 rata-rata kuantitas pembelian selama setahun.

Tabel 2 Rata-Rata Kuantitas Pembelian Selama Setahun.

\begin{tabular}{cc}
\hline Tahun & Rata-rata kuantitas pembelian \\
\hline 2016 & $13.619,5 \mathrm{~kg}$ \\
2017 & $13.803,16 \mathrm{~kg}$ \\
2018 & $13.755,41 \mathrm{~kg}$ \\
\hline
\end{tabular}

Dalam pembelian bahan baku kawat baja PT Chuhatsu Indonesia menjalin hubungan kerja sama dengan pemasok dalam ikatan kontrak selama satu tahun, dan menentukan harga pembelian bahan baku kawat baja perkilonya. Berikut tabel 3 harga bahan baku kawat baja perkilo gram.

Tabel 3 Harga Bahan Baku Kawat Baja Perkilo Gram

\begin{tabular}{cc}
\hline Tahun & Harga bahan baku kawat baja perkilo gram \\
\hline 2016 & Rp 14.600 \\
2017 & $R p 14.800$ \\
2018 & $R p 15.000$ \\
\hline
\end{tabular}

Untuk melakukan pembelian maka perusahaan terlebih dahulu melakukan pemesanan dengan pemasok dalam frekuensi pembelian 12 kali dalam setahun. Berikut tabel 4,5,6 biaya pemesanan periode tahun 2016, 2017,2018:

Tabel 4 Biaya Pemesanan Tahun 2016

\begin{tabular}{lcc}
\hline \multicolumn{1}{c}{ Jenis Biaya } & \multicolumn{1}{c}{ Biaya } \\
\hline Biaya Telpon dan Faximile & Rp & 280.000 \\
Biaya Penerimaan & Rp 1.000 .000 \\
Total Biaya & Rp 1.280 .000 \\
\hline \multicolumn{1}{c}{ Tabel 5 Biaya Pemesanan Tahun 2017 } \\
\multicolumn{1}{c}{ Jenis Biaya } & Biaya \\
\hline Biaya Telpon dan Faximile & Rp & 290.000 \\
Biaya Penerimaan & Rp 1.100 .000 \\
Total Biaya & Rp 1.390 .000 \\
\hline
\end{tabular}


Tabel 6 Biaya Pemesanan Tahun 2018

\begin{tabular}{ll}
\hline \multicolumn{1}{c}{ Jenis Biaya } & \multicolumn{1}{c}{ Biaya } \\
\hline Biaya Telpon dan Faximile & Rp 300.000 \\
Biaya Penerimaan & Rp 1.200 .000 \\
Total Biaya & Rp 1.500 .000 \\
\hline
\end{tabular}

Dari tabel diatas Jadi biaya pemesanan bahan baku kawat baja selama setahun dalam perhitungan kebijakan perusahaan periode 2016, 2017, 2018 adalah frekuensi pembelian dikalikan dengan biaya pemesanan setiap kali pesan dalam setahun. Berikut tabel 7 biaya pemesanan:

Tabel 7 Biaya Pemesanan

\begin{tabular}{ll}
\hline Tahun & Biaya pemesaan \\
\hline 2016 & Rp 15.360 .000 \\
2017 & Rp 16.680 .000 \\
2018 & Rp 18.000 .000 \\
\hline
\end{tabular}

Besar biaya penyimpanan adalah dihitung berdasar persentase harga yang disimpan digudang setiap tahunnya. Biaya penyimpanan meliputi:

Biaya kerusakan dan kehilangan $1 \%$ dari harga bahan baku kawat baja perkilonya selama setahun, biaya penanganan persediaan $1 \%$ dari harga bahan baku kawat baja perkilonya selama setahun, biaya fasilitas penyimpanan $1 \%$ dari harga bahan baku kawat baja perkilonya selama setahun. Total persentase penyimpanan dari perusahaan sebesar 3\% dari harga bahan baku kawat baja perkilonya selama setahun. Dari total persentase penyimpanan bahan baku kawat baja diatas dapat diketahui biaya peyimpanan perkilo gramnya adalah:

Tabel 8 Biaya Penyimpanan Perkilo Gram dalam Setahun

\begin{tabular}{cc}
\hline Tahun & Biaya Simpan \\
\hline 2016 & Rp 438 \\
2017 & Rp 444 \\
2018 & Rp 450 \\
\hline
\end{tabular}

Dari tabel diatas jadi biaya penyimpanan bahan baku selama setahun dalam perhitungan kebijakan perusahaan periode 2016, 2017, 2018 adalah rata-rata kuantitas bahan baku dibagi 2 dikalikan harga bahan baku perkilo gramnya dikalikan total persentase 3\%. Berikut tabel 9 biaya penyimpanan:

\begin{tabular}{cc}
\multicolumn{2}{c}{ Tabel 9 Biaya Penyimpanan Pertahun } \\
\hline Tahun & Biaya penyimpanan \\
\hline 2016 & Rp 2.982.670,5 \\
2017 & Rp 3.064.301,52 \\
2018 & Rp 3.094.967,25
\end{tabular}

Dengan demikian maka dapat diketahui total biaya persediaan bahan baku baku kawat baja dalam perhitungan kebijakan perusahaan selama satu tahun periode 2016, 2017, 2018 adalah biaya penyimpanan ditambahkan dengan biaya pemesanan. Berikut tabel 10 total biaya persediaan:

Tabel 10 Total Biaya Persediaan Bahan Baku Selama Setahun

\begin{tabular}{cccll}
\hline No & Tahun & Biaya pemesanan & Biaya penyimpanan & \multicolumn{1}{c}{ Total biaya } \\
\hline 1 & 2016 & $R p 15.360 .000$ & Rp 2.982.670,5 & Rp 18.342.670,50 \\
2 & 2017 & $R p 16.680 .000$ & Rp 3.064.301,52 & Rp 19.744.301,52 \\
3 & 2018 & $R p 18.000 .000$ & Rp 3.094.967,25 & Rp 21.094.967,25 \\
\hline
\end{tabular}


2. Pengolahan Data

a. Kuantitas pemesanan yang optimal. Berdasarkan data pemakaian bahan baku kawat baja maka dapat dilihat basarnya kuantitas pemesanan yang paling ekonomis dengan metode EOQ dapat ditentukan dengan rumus sebagai berikut:

$$
\mathrm{Q}=\sqrt{\frac{2 \times \mathrm{O} \times \mathrm{D}}{\mathrm{C}}}
$$

1. Tahun 2016

$$
\begin{aligned}
& =\sqrt{\frac{2 \times 1.280 .000 \times 163.379}{438}} \\
& =\sqrt{954.909 .223,74} \\
& =30.901,60 \mathrm{~kg}
\end{aligned}
$$

2. Tahun 2017

$$
\begin{aligned}
& =\sqrt{\frac{2 \times 1.390 .000 \times 165.643}{444}} \\
& =\sqrt{1.037 .134 .099,09} \\
& =32.204,56 \mathrm{~kg}
\end{aligned}
$$

3. Tahun 2018

$$
\begin{aligned}
& =\sqrt{\frac{2 \times 1.500 .000 \times 164.620}{450}} \\
& =\sqrt{1.097 .466 .666,66} \\
& =33.128,03 \mathrm{~kg}
\end{aligned}
$$

b. Total biaya persediaan tahunan yang minimum. Untuk menentukan biaya persediaan bahan baku kawat baja tahunan yang minimum maka dapat diketahui perhitungannya dengan rumus sebagai berikut:

$$
\mathrm{T}^{*} \quad=\frac{\mathrm{C} \cdot \mathrm{Q} *}{2}+\frac{\mathrm{O} \cdot \mathrm{D}}{\mathrm{Q} *}
$$

Tahun 2016

$$
\begin{aligned}
& =\frac{438 \times 30.901,60}{2}+\frac{1.280 .000 \times 163.379}{30.901,60} \\
& =\operatorname{Rp} 6.767 .450,4+\operatorname{Rp} 6.767 .452,81 \\
& =\operatorname{Rp~13.534.903,21~}
\end{aligned}
$$

Tahun 2017

$$
\begin{aligned}
& =\frac{444 \times 32.204,56}{2}+\frac{1.390 .000 \times 165.643}{32.204,56} \\
& =\operatorname{Rp} 7.149 .412,32+\operatorname{Rp} 7.149 .415,17 \\
& =\operatorname{Rp~14.298.827,49~}
\end{aligned}
$$

Tahun 2018

$$
\begin{aligned}
& =\frac{450 \times 33.128,03}{2}+\frac{1.500 .000 \times 164.620}{33.128,03} \\
& =\operatorname{Rp} 7.453 .806,75+\operatorname{Rp} 7.453 .808,75 \\
& =\operatorname{Rp~14.907.615,5~}
\end{aligned}
$$

c. Perhitungan dengan metode JIT 
Jumlah pengiriman optimal untuk setiap kali pesan. Berdasarkan kuantitas pesanan optimal dari perhitungan EOQ maka dapat dilihat jumlah pengiriman JIT yang optimal setiap kali pesan pada bahan baku kawat baja pada periode tahun 2016, 2017, 2018 dengan rumus perhitungan sebagai berikut:

$$
\text { na } \quad=\left(\frac{Q^{*}}{2 . \mathrm{a}}\right)^{2}
$$

Diketahui rata-rata target spesifik persediaan dalam unit adalah:

Tahun $2016=11.000 \mathrm{~kg}$

Tahun $2017=11.250 \mathrm{~kg}$

Tahun $2018=9.125 \mathrm{~kg}$

1. Tahun 2016

$$
\begin{aligned}
& =\left(\frac{30.901,60}{2 \times 11.000}\right)^{2} \\
& =(1,40)^{2}=1,96 \text { dibulatkan } 2 \mathrm{kali} \\
& \text { 2. Tahun } 2017=\left(\frac{32.204,56}{2 \times 11.250}\right)^{2} \\
& =(1,43)^{2}=2,04 \text { dibulatkan } 2 \text { kali } \\
& =(1,81)^{2} \quad=3,27 \text { dibulatkan } 3 \text { kali }
\end{aligned}
$$$$
\text { 3. Tahun } 2018=\left(\frac{33.128,03}{2 \times 9.125}\right)^{2}
$$

d. Kuantitas pesanan untuk setiap kali pesan. Berdasarkan kuantitas pesanan yang optimal dari perhitungan EOQ maka dapat dilihat kuantitas pesanan JIT untuk setiap kali pesan pada bahan baku kawat baja untuk pembuatan produk coil spring selama setahun periode tahun 2016, 2017, 2018 dengan rumus perhitungan sebagai berikut:

$\mathrm{Qn}=\sqrt{\mathrm{na}} \cdot \mathrm{Q}^{*}$

1. Tahun 2016

$$
\begin{aligned}
& =\sqrt{2} \times 30.901,60 \\
& =43.701,46 \mathrm{~kg}
\end{aligned}
$$

2. Tahun 2017

$$
\begin{aligned}
& =\sqrt{2} \times 32.204,56 \\
& =45.544,12 \mathrm{~kg}
\end{aligned}
$$

3. Tahun 2018

$$
\begin{aligned}
& =\sqrt{3} \times 33.128,03 \\
& =57.379,43 \mathrm{~kg}
\end{aligned}
$$

e. Kuantitas pengiriman optimal setiap kali pengiriman. Berdasarkan kuantitas pesanan JIT maka dapat dilihat kuantitas pengiriman JIT yang optimal untuk setiap kali pengiriman selama setahun pada bahan baku kawat baja dalam periode tahun 2016, 2017, 2018 dengan rumus perhitungan sebagai berikut:

$\mathrm{q}=\frac{\mathrm{Qn}}{\mathrm{na}}$

1. Tahun $2016=\frac{43.701,46}{2}$

$$
=21.850,73 \mathrm{~kg}
$$

2. Tahun $2017=\frac{45.544,12}{2}$

$$
=22.772,06 \mathrm{~kg}
$$

3. Tahun $2018=\frac{57.379,43}{3}$

$$
=19.126,47 \mathrm{~kg}
$$

f. Frekuensi pembelian JIT. Berdasarkan data pemakaian bahan baku kawat baja maka dapat dilihat frekuensi pembelian JIT dalam setahun pada periode 2016, 2017, 2018 dengan rumus sebagai berikut:

$\mathrm{n}=\frac{\mathrm{D}}{\mathrm{Qn}}$

1. Tahun $2016=\frac{163.379}{43.701,46}=3,7$ dibulatkan menjadi 4 kali 
2. Tahun $2017=\frac{165.643}{45.544,12}=3,6$ dibulatkan menjadi 4 kali

3. Tahun $2018=\frac{164.620}{57.379,43}=2,8$ dibulatkan menjadi 3 kali

g. Total biaya persediaan dengan sistem just in time. Berdasarkan hasil perhitungan total biaya persediaan dengan metode EOQ, maka dapat diketahui total biaya persediaan dengan sistem just in time selama setahun pada periode 2016, 2017, 2018 dengan rumus sebagai berikut:

$\mathrm{T} j i t=\frac{1}{\sqrt{\mathrm{n}}}\left(\mathrm{T}^{*}\right)$

Keterangan:

T jit : Total biaya tahunan yang minimum untuk sistem JIT (Sholehudin, 2017)

1. Tahun 2016

$=\frac{1}{\sqrt{4}} \times \operatorname{Rp} 13.534 .903,21$

$=\operatorname{Rp} 6.767 .451,60$

2. Tahun 2017

$=\frac{1}{\sqrt{4}} \times \operatorname{Rp} 14.298 .827,49$

$=\operatorname{Rp} 7.149 .413,74$

3. Tahun 2018

$=\frac{1}{\sqrt{3}} \times \operatorname{Rp} 14.907 .615,5$

$=\operatorname{Rp} 8.606 .915,82$

Dari hasil perhitungan yang telah dilakukan, maka dapat dilihat perbandingan total biaya persediaan bahan baku kawat baja antara kebijakan perusahaan dengan menggunakan metode just in time (JIT) selama setahun pada periode 2016, 2017, dan 2018. Dengan mengetahui perbandingannya, perusahaan akan mengetahui metode mana yang akan menghasilkan biaya yang paling minimum dan bila diterapkan akan menghasilkan keuntungan. Berikut dibawah ini tabel 11 perbandingannya.

Tabel 11. Perbandingan total biaya persediaan antara kebijakan perusahaan dan sistem just in time

\begin{tabular}{ccccc}
\hline No & Tahun & $\begin{array}{c}\text { Kebijakan } \\
\text { perusahaan }\end{array}$ & Metode just in time & Penghematan \\
\hline 1 & 2016 & $\operatorname{Rp~18.342.670,5}$ & $\operatorname{Rp~6.767.451,60~}$ & $\operatorname{Rp~11.575.218,9~}$ \\
2 & 2017 & $\operatorname{Rp~19.744.301,52~}$ & $\operatorname{Rp~7.149.413,74}$ & $\operatorname{Rp~12.594.887,78}$ \\
3 & 2018 & $\operatorname{Rp~21.094.967,25}$ & $\operatorname{Rp~8.606.915,82~}$ & $\operatorname{Rp~12.488.051,43~}$ \\
\hline
\end{tabular}

Berdasarkan tabel diatas membuktikan bahwa kebijakan pengendalian persediaan yang dilakukan perusahaan belum maksimal dan terlihat hasil dari metode just in time menunjukan hasil yang lebih maksimal dengan biaya yang lebih minimum dibandingkan dengan kebijakan yang dilakukan perusahaan.

\section{SIMPULAN}

Dengan menggunakan metode persediaan tepat waktu (just In time) maka perusahaan dapat mengetahui jumlah pengiriman optimal bahan baku kawat baja untuk setiap kali pesan dalam setahun periode 2016 adalah sebanyak 2 kali, periode 2017 sebanyak 2 kali, dan periode 2018 sebanyak 3 kali. Kuantitas pengiriman yang optimal untuk setiap kali pengiriman periode tahun 2016 sebanyak 21.850,73 kg, periode tahun 2017 sebanyak $22.772,06 \mathrm{~kg}$, dan periode tahun 2018 sebanyak 19.126,47 kg. Kuantitas pesanan bahan baku kawat baja untuk setiap kali pesan periode tahun 2016 sebanyak 43.701,46 kg, periode tahun 2017 sebanyak 45.544,12 kg, dan periode tahun 2018 sebanyak 57.379,43 kg. Dan frekuensi pembelian bahan baku kawat baja periode tahun 2016 sebanyak 4 kali, periode 2017 sebanyak 4 kali, dan 2018 sebanyak 3 kali.

Dari perhitungan dengan metode tepat waktu (just in time) maka dapat diketahui total biaya persedian periode tahun 2016 sebesar Rp 6.767.451,60, periode tahun 2017 sebesar Rp 7.149.413,74, dan periode tahun 
2018 sebesar Rp 8.606.915,82. Maka penghematan yang didapat oleh perusahaan dalam biaya persediaan bahan baku kawat baja periode tahun 2016 sebesar Rp 11.575.218,9, periode 2017 sebesar Rp 12.594.887,78, dan periode 2018 sebesar Rp 12.488.051,43. Dengan ini membuktikan bahwa terlihat hasil dari metode tepat waktu (just in time) menunjukan hasil yang lebih maksimal dengan biaya yang lebih minimum dibandingkan dengan kebijakan yang dilakukan perusahaan.

\section{UCAPAN TERIMA KASIH}

Terima kasih kepada semua pihak yang telah berkontribusi dalam penelitian ini, sehingga penelitian dapat terlaksana dengan baik. Dalam penelitian tugas akhir tentunya tidak lepas dari kekurangan dan jauh dari kesempurnaan. Kritik dan saran yang bertujuan membangun menjadi lebih baik. Semoga penelitian tugas akhir ini dapat berguna dan bermanfaat bagi penulis dan pembacanya.

\section{DAFTAR PUSTAKA}

Deitiana, Tita. (2011). Manajemen Oprasional Strategi dan Analisa (Services dan Manufaktur). Jakarta: Mitra Wacana Media.

Hakim, L. (2015). Implementasi just in time dalam meningkatkan produktivitas dan efisiensi biaya produksi. Journal of Research and Technology. 1(1), 1-8.

Nasution, H. A., dan Prasetyawan, Y. (2008). Perencanaan dan Pengendalian Produksi Edisi Pertama. Yogyakarta: Graha Ilmu.

Pristianingrum, N. (2017). Peningkatan Efisiensi Dan Produktivitas Perusahaan Manufaktur Dengan Sistem Just In Time. Jurnal Ilmiah Ilmu Akuntansi, Keuangan dan Pajak. 1(1), 41-53.

Sholehudin, M dan Wuryani, E. (2017). Analisis metode persediaan tepat waktu (just in time) sebagai dasar pengendalian persediaan bahan baku pembantu. Jurnal Akuntansi Unesa. 5(2), 1-25. 